"Mircea cel Batran" Naval Academy Scientific Bulletin, Volume XIX - 2016 - Issue 1

Published by "Mircea cel Batran" Naval Academy Press, Constanta, Romania // The journal is indexed in:

PROQUEST / DOAJ / DRJI / JOURNAL INDEX / I2OR / SCIENCE LIBRARY INDEX / Google Scholar / Crossref /

Academic Keys / ROAD Open Access / OAJI / Academic Resources / Scientific Indexing Services / SCIPIO

\title{
ON SOME LINEAR AND POSITIVE OPERATORS ON SLOT
}

\section{Ligia-AdrianaSPORIS $^{1}$}

Traian FLOREA ${ }^{2}$

\section{Corneliu MOROIANU ${ }^{3}$}

${ }^{1}$ Lecturer PhD, Dep. IMAN, Naval Academy "Mircea cel Batran", Constanta, 1 Fulgerului Street

2 Professor Eng., Dep. IMAN, Naval Academy "Mircea cel Batran", Constanta, 1 Fulgerului Street

${ }^{3}$ Assoc. Prof., PhD, Dep. IMAN, Naval Academy "Mircea cel Batran", Constanta, 1 Fulgerului Street

Abstract: The aim of this note is to discuss about the behavior and the properties of some linear and positive operators on SLOT

\section{§1. Introduction}

- Let be a locally compact Hausdorff space and $(G, V)$, a locally convex cone.

- Let $\psi: X \rightarrow R_{+}^{*}$, a weight on_ and $v_{\psi}=\left\{v_{\psi} \mid v_{\psi}=\frac{v}{\psi}, \mathrm{v} \in \mathrm{V}\right\}$.

- Let consider the following set: $C_{s}(X ; G)=\{f: X \rightarrow G \mid f$ continuă în raport cu topologia simetrică pe $\mathrm{G}\}$

- Endowed with the topology of uniform convergence determined by: $f \leq g+\bar{v} \Leftrightarrow f(x) \leq g(x)+v,(\forall) x \in X$, unde $\overline{\mathrm{v}}: \mathrm{X} \rightarrow \mathrm{G}, \overline{\mathrm{v}}(\mathrm{x})=v, \mathrm{v} \in \mathrm{V},\left(C_{S}(X ; G), \bar{V}\right)$ becomes a locally convex cone.

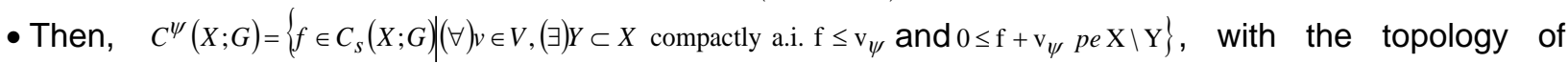
uniform convergence determined by: $f \leq g+v_{\psi} \Leftrightarrow \psi f \leq \psi g+\bar{v}$, is also a locally convex cone, named Nachbin cone relative to the weight $\psi$.

- Let $M \subset G^{*}$ and $M_{X}^{\psi}=\left\{\mu_{x} \mid \mu_{X} \in\left(C_{S}(X ; G)\right)^{*}, \mu \in \mathrm{M}\right.$ ssi $\left.\mathrm{x} \in \mathrm{X}\right\}$, where $\mu_{X}: C^{\psi}(X ; G) \rightarrow R, \mu_{\mathrm{x}}(f)=\mu(f(x))$.

- Definition 1: If $G_{0} \subset C^{\psi}(X ; G)$ is a sub coneand $\mu_{X} \in M_{X}^{\psi}$, then:

a) $f \in C^{\psi}(X ; G)$ is a $G_{0}$-superharmonic in $\mu_{X} \Leftrightarrow \Leftrightarrow\left\{\begin{array}{l}1 . \mu_{\mathrm{X}}(f)<+\infty \\ \text { 2. }(\forall) \Phi \in\left(C^{\psi}(X ; G)\right)^{*}, \Phi \underset{G_{0}}{\prec} \mu_{X} \Rightarrow \Phi(f) \leq \mu_{X}(f)\end{array}\right.$

b) $f \in C^{\psi}(X ; G)$ is a $G_{0}$ - subharmonic în $\mu_{X} \Leftrightarrow \Leftrightarrow\left\{\begin{array}{l}1 . \mu_{X}(f)<+\infty \\ \text { 2. }(\forall) \Phi \in\left(C^{\psi}(X ; G)\right)^{*}, \mu_{\mathrm{X}} \underset{G_{0}}{\prec} \Phi \Rightarrow \mu_{X}(f) \leq \Phi(f)\end{array}\right.$

§2.The main results



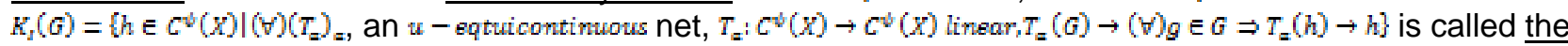
Korovkin cone associated to $G$.

- The next result gives a characterization of the Korovkin cone associated to a subspace $G$ of $C^{\psi}(X)$.

- Proposition 3: Let $G \subset C^{\psi}(X)$, a subspace. Then the followings are equivalent:

1. $f \in K_{\mathrm{I}}(G)$;

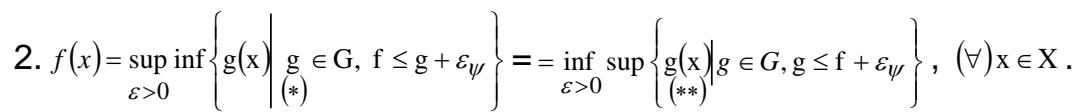

- Note 4:

$$
\begin{gathered}
(*) \Leftrightarrow f(x)=\hat{f}\left(\varepsilon_{X}\right) \Leftrightarrow f \in \operatorname{Sup}_{G}\left(\varepsilon_{X}\right) . \\
(* *) \Leftrightarrow f(x)=\breve{f}\left(\varepsilon_{X}\right) \Leftrightarrow f \in \operatorname{Sub}_{G}\left(\varepsilon_{X}\right) .
\end{gathered}
$$

- Definition 5: $S \subset C^{\psi}(X)$ is called Korovkin $C^{\psi}(x)$ iff $(\forall) \mathrm{f} \in \mathrm{C}^{\psi}(X)_{+}, \mathrm{f} \in \operatorname{Sup}_{\mathrm{G}_{0}}\left(M_{X}^{\psi}\right)$, where $G_{0}$ is a sub cone generated by $S$ and $M=\bar{R}^{*}$.

- Examples 6:

1. $X=[0,1]$ and $\psi=1 \Rightarrow C^{\psi}(X)=C[0,1]$. 
"Mircea cel Batran" Naval Academy Scientific Bulletin, Volume XIX - 2016 - Issue 1

Published by "Mircea cel Batran" Naval Academy Press, Constanta, Romania // The journal is indexed in:

PROQUEST / DOAJ / DRJI / JOURNAL INDEX / I2OR / SCIENCE LIBRARY INDEX / Google Scholar / Crossref /

Academic Keys / ROAD Open Access / OAJI / Academic Resources / Scientific Indexing Services / SCIPIO

$S=\left\{1,-\mathrm{x}, \mathrm{x}^{2}\right\}$ is a Korovkin system ${ }^{+}$for $C[0,1]$, because thesub cone generated by $S, G_{0}$ contains all the positive constants and all functions, $f(x)=\left(x-x_{0}\right)^{2}, x_{0} \in[0,1]$.

2. $X \in R, \psi=1 \Rightarrow C^{\psi}(X)=C_{0}(R)$.

$S=\left\{\mathrm{e}^{-\mathrm{x}^{2}},-\mathrm{xe}^{-\mathrm{x}^{2}}, \mathrm{x}^{2} e^{-x^{2}}\right\}$ is a Korovkin system ${ }^{+}$for $C_{0}(R)$.

The following results give characterizations for Korovkin systems and Korovkin system ${ }^{+}$for $C^{\psi}(X)$.

- Proposition 7: Let $x$, be a locally compact Hausdorff space; $\psi$, a weight on $x$ and $G \subset C^{\psi}(x)$, a subspace. Then, FAE:

1. $G$ is a Korovkin system for $C^{\psi}(X)$.

2. a) $(\exists) k \in G, \mathrm{k}(\mathrm{x}) \neq 0$;

b)

$(\forall) \varepsilon>0,(\forall) K \subset X$ compact, $(\forall) x \in X$ so

that $x \notin K,(\exists) k \in G,(\exists) u \in C^{\psi}(X)_{+}$so

that $\|u\|_{\psi} \leq \varepsilon, 0 \leq \mathrm{h}+\mathrm{u}, 1 \leq \mathrm{h}+\mathrm{u}$ by $K^{\prime}, \mathrm{h}(\mathrm{x})+u(x)<\varepsilon \quad\left(\right.$ where $\left.\|\cdot\|_{\psi}:\|f\|_{\psi} \underset{x \in X}{\Delta}=\sup _{x \in} \psi(x)\|f(x)\|\right)$.

- Proposition 8: Let $S \subset C^{\psi}(X)$. FAE:

1. $S$ is a Korovkin sistem ${ }^{+}$for $C^{\psi}(X)$.

2. $(\forall) \mathrm{x} \in \mathrm{X},(\forall) \mu \in \mathrm{M}_{b}^{+}(X): \psi \mu(\mathrm{g}) \leq g(x),(\forall) \mathrm{g} \in \mathrm{S} \Rightarrow(\exists) \lambda \in[0,1]$ so that $\psi \mu=\lambda \varepsilon_{X}$.

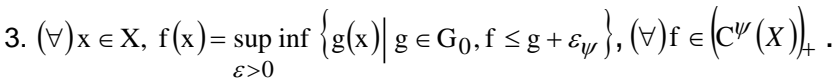

- Note 9:

1) If we have $S$ a Korovkin sistem ${ }^{+}$for $C^{\psi}(X)$ and is $S$ contains $g_{0} g_{0}<0$, then it is a Korovkin system for $C^{\psi}(x)$.

The result form above gives us the possibility to obtain some results for $\left(C^{\psi}(X ; G), V_{\psi}\right)$ '

- Proposition 10:

Let $(G, V)$, be a locally convex cone and $G$ be a linear space, $G_{0}$, a sub cone of $C^{\psi}(X ; G),(X$, locally compact Hausdorff space and $\psi$ a weight on $X)$ and $S$, a Korovkin system ${ }^{+}$for $C^{\psi}(X)$.

Iff: (i) $(\forall) a \in G(\forall) v \in V_{0}(\exists) 0 \leq e \in G$ so that $a \leq e+v$ and $\left.[g-e]_{g} \in S \subset G_{g}\right]$

(ii) $(\forall) \mathrm{a} \in \mathrm{G},(\exists) p \in C^{\psi}(X)+$ So that $(p \cdot a) \in G_{0}$, then, we hawe: $C^{\psi}(X ; G) \equiv \operatorname{Sup}_{G_{0}}\left(\left(G^{*}\right)_{X}^{\psi}\right)$.

- Corollary 11: If $X$ is a compact space and $B=\bar{S}(0 ; 1)$ in $R^{n}$ and $s$ is a Korovkin system of positive functions for $c(X)$ then $\tilde{s}=\left\{f-b \mid f \in S \cup\left\{c \mid c \in \operatorname{Comv}\left(R^{n}\right)\right\}\right]$ is a Korovkin system for $c\left(X_{i} C \operatorname{Comv}\left(R^{n}\right)\right)$.

\section{BIBLIOGRAPHY}

[1] Altomare, F.:Su alcuni aspetti della teoria dell'approssimazione di tipo Korovkin, Quaderno dell'Istituto di Analisi Matematica dell'Università di Bari, 1980.

[2] Altomare, F. and Campiti, M.: Korovkin - type Approximation Theory and its Applications, de Gruyter Studies in Mathematics, vol.17, 1994.

[3] Bauer, H.: Approximation and abstract boundaries, Amer. Math. Munthly, 1978.

[4] Bauer, H., Leha, G. and Papadopoulou, S.: Determination of Korovkin closures, Math. Z., 1979.

[5] Berens, H. and Lorentz, G.G.: Theorems of Korovkin type for positive linear operators on Banach lattices,

in: Approximation Theory ( Proc. Internat. Sympos., Univ. Texas, Austin, Tex.1973), Academic Press, New York, 1973.

[6] Cristescu, R.: Clase de operatori pe spaţii ordonate, Structuri de ordine în analiza funcţionalã, vol.1, Ed. Acad., 1986.

[7] De Vore, R.A.The Approximation of Continuous Functions by Positive Linear Operators, Lecture Notes in Math., Springer-Verlag, Heidelberg-Berlin-New York, 1972.

[8] Keimel, K. and Roth, W.: Ordered Cones and Approximation, Preprint 1987, 1989. 
"Mircea cel Batran" Naval Academy Scientific Bulletin, Volume XIX - 2016 - Issue 1

Published by "Mircea cel Batran" Naval Academy Press, Constanta, Romania /I The journal is indexed in: PROQUEST / DOAJ / DRJI / JOURNAL INDEX / I2OR / SCIENCE LIBRARY INDEX / Google Scholar / Crossref I Academic Keys I ROAD Open Access / OAJI / Academic Resources / Scientific Indexing Services / SCIPIO

[9] Roth, W.: Families of convex subsets and Korovkin-type theorems in locally convex spaces, Rev. Roumaine Math. Pures Apll., 1989.

[10] Sporiş, L.A.: Asupra închiderilor Korovkin şi subspaţii Korovkin pentru operatori liniari şi pozitivi, Seminarul ştiinţific Spaţii liniare ordonate topologice, Bucureşti, 1998.

[11] Sporiş, L.A.: On some aspects of Korovkin Approximation Theory, Al-XVII-lea Colocviu de Spaţii liniare ordonate topologice, Sinaia, 1998.

[12] Sporiş, L.A.: Conuri Korovkin în SRLC, Seminarul ştiinţific Spaţii liniare ordonate topologice, Bucureşti, 2000. 